\begin{tabular}{|c|c|c|c|}
\hline $\begin{array}{c}\text { RESEARCH } \\
\text { ARTICLE } \\
\end{array}$ & $\begin{array}{r}\text { ADVANCE RESEAR } \\
\text { Volume } 9 \mid \text { Issu }\end{array}$ & OCIAL SCIENCE & \\
\hline $0=$ & DOI: 10.15740/HAS/ARJSS/9.1/41-43 & Visit us : www.researchjournal.co.in & \\
\hline
\end{tabular}

\title{
Studies of child neglect (Psychological abuse) and gender disparities in different socio- economic status groups
}

Shashi Singh ${ }^{1 *}$, Anjali Mathur ${ }^{2}$ and Anamika Singh ${ }^{3}$

${ }^{1}$ VNS Girls P.G. College, Faizabad (U.P.) India

${ }^{2}$ Ethelind College of Home Science, Sam Higginbottom Institute of Agriculture, Technology and Sciences, Allahabad (U.P.) India

${ }^{3}$ C.S.A University of Agriculture and Technology, Kanpur (U.P.) India

(Email: shashisbisen@gmail.com)

\section{ARTICLE INFO :}

Received

Revised

: 25.12 .2017

Accepted

: 23.04 .2018

: 09.05 .2018

KEY WORDS :

Abuse, Barrier, Campaigns, Prevalence, Prevent, Maltreatment

HOW TO CITE THIS ARTICLE :

Singh, Shashi, Mathur, Anjali and Singh, Anamika (2018). Studies of child neglect (Psychological abuse) and gender disparities in different socio- economic status groups. Adv. Res. J. Soc. Sci., 9 (1) : 41-43, DOI: 10.15740/HAS/ARJSS/ 9.1/41-43.

Copyright@2018 : Hind Agri -

Horticultural Society

*Author for correspondence

\begin{abstract}
The present study were attempted to find out the prevalence of child neglect among children and prevalence of gender disparities in abuse across three socio-economic groups in Allahabad district. A total sample of 180 children in age group of 9-18 years from three socio-economic status families were selected using stratified random sampling technique. Sixty respondent and their parents from each socio-economic group ( 30 boys and 30 girls) were selected for the study. Socio-economic status scale was use to assess the socio-economic status of the respondents. Self-made interview schedule for parents and children was used to assess the prevalence of abuse. The present study indicated that child neglect was more prevalent in lower socio-economic group among boys and girls followed by middle and upper socio-economic group. Socio-economic status had a significant effect $(\mathrm{P}<.01)$ and gender had a non-significant effect on the prevalence of psychological abuse. The study indicated that parents were mostly responsible for inflicting psychological abuse on children. In the present study, it can be concluded that the child neglect was prevalent among children in all the socio-economic groups and it was suggested that awareness campaigns, role of mass media, law of policies for protection of children's rights can prove to be helpful in preventing child abuse.
\end{abstract}

